\title{
PRECONDITIONS FOR THE SUCCESSFUL INTEGRATION OF DISABLED PERSONS INTO THE LABOUR MARKET
}

\author{
Ingrida Baranauskienè \\ Klaipeda University, Lithuania \\ Ilona Dobrovolskytė \\ Šiauliai University, Lithuania
}

\begin{abstract}
Low activity level of disabled persons is closely related to the lack of their vocational skills, qualification, experience and motivation. All of the above mentioned elements are interrelated and can be the cause of each other.

The aim of the research - to create the grounded theory for the successful integration of disabled persons into the labour market after their vocational rehabilitation. The given paper presents a model for the successful integration of disabled persons into the labour market. The model can be further used in order to improve the vocational rehabilitation process and, consequently, increase the number of employed disabled persons. Such integration does not only improve the employment indicators of disabled persons but also contributes to their socialization and wellbeing.
\end{abstract}

Keywords: disabled persons, integration, labour market, vocational rehabilitation.

\section{Introduction}

An individual's work and professional activities play significant importance in the process of one's socialization. Both disabled persons, looking for a job, as well as the employers, involved in the process of their employment, face certain difficulties and these have been actively discussed in Lithuania and the European Union (Baranauskienè \& Juodraitis, 2008). The efficiency of vocational rehabilitation of disabled persons in Lithuania is based taking into account the number of employed people after the completion of a rehabilitation programme within the period of 6 months. According to the data of the Lithuanian Labour Exchange, being in charge of the efficiency of provided services, 65.7 percent of disabled persons were employed in 2014. Such high percentage has been achieved due to the fact that disabled persons could either acquire a new specialization or improve, rebuild their lost vocational skills (Lithuanian Labour Exchange, Results, 2015). 
The scholars (Bond, Resnick et al., 2001; Drebing, Bell et al., 2012; Mueser, Becker et al., 1997; Siu, Tsang, \& Bond, 2010) state that work is one of the therapy forms, allowing an individual to satisfy not only one's own physical but also emotional needs. While employed, disabled persons are often surrounded by other people, more frequently participate in social life and feel being valued and being active participants of social life rather than passive recipients of public services (Drebing, Bell et al., 2012). Vocational rehabilitation of disabled persons is based on the assumption that work does not only improve activity, social contacts, etc. but may also promote gains in related areas such as self-esteem and quality of life, as work and employment are a step away from dependency and a step to integration into society (Rossler, 2006). Low activity level of disabled persons is closely related to the lack of their vocational skills, qualification, experience and motivation. All of the above mentioned elements are interrelated and can be the consequence and / or the cause of each other.

Research problem - identify the preconditions for the successful integration of disabled persons into the labour market.

Research object -integration of disabled persons into the labour market.

Field of research - disabled persons after vocational rehabilitation and their integration into the labour market.

Research aim - to create the grounded theory for the successful integration of disabled persons into the labour market after their vocational rehabilitation.

Research data collection: the research data has been collected on the basis of a semi-structured interview. The interview questions have been designed in order to identify the acquired experience of disabled persons, to evaluate provided vocational rehabilitation services, to identify what has predetermined their life changes after vocational rehabilitation, focusing in particular on preconditions for the success, i.e. the situation of disabled persons on the labour market. Each respondent has been informed about the aim of the research, its implementation stages and interview questions as well as instructed with regards to the confidentiality of the research. Moreover, the respondents have been asked whether they agree for the interview to be recorded and later transcribed. Given the respondents' consent, the interviews have been scheduled during mutually convenient day and time for both parties.

Research participants: 6 disabled persons, having undergone vocational rehabilitation, have been interviewed. Four of them are currently successfully employed; the remaining two are still looking for a job and hope to be employed soon. Average age of the respondents is 39,5. The respondent group comprised one male and 5 females. The respondents have undergone vocational rehabilitation for the first time. One respondent had mental disability; others physical disability: 3 acquired and 1 congenital. The disabled persons had 30-55 $\%$ capacity for work. In accordance with the legal regulations set by the Disability 
and Working Capacity Assessment Office, if a disabled person is recognised as having 30-55\% capacity for work, he/she is deemed to be partly capable for work, can work under usual working conditions, subject to recommendations provided for in the Conclusion on the Nature and Conditions of Work (the Order of the Minister of the Social Security and Labour and the Minister of Health of the Republic of Lithuania on the Description of the Criteria for the Assessment of the Level of Working Capacity and Approval of the Description of the Procedure for the Assessment of the Level of Working Capacity, dated 21 March, 2005 No. A178/V-179).

Research empirical data analysis. The research data analysis has been done by following A. Strauss and J. Corbin's insights: 1) data coding; 2) data analysis. The collected interview data has been transcribed. The transcribed data has been coded by events. Afterwards, the first memos - insights - have been written in paragraphs. Having transcribed the whole interview, the data coding line by line has been done. The data coding has been done on an interpretative basis. According to A. Strauss and J. Corbin such coding has a systemic nature and comprises text transcription, paraphrasing, conceptualization and categorization.

\section{Axial Coding and Description of the Phenomena}

Two major categories have been identified: the role of social care/welfare institutions and personal motivation. Each phenomenon has been analysed separately by following the paradigmatic causal-consequential model.

Everything is "in the hands of" social care/welfare institutions: "the labour exchange has created a workplace specially for me". This phenomenon shows that the successful integration of disabled persons into the labour market depends on the role of social care/welfare institutions and the quality of their provided services.

The importance of the role of social care/welfare institutions and the quality of their provided services have been evidenced by the following causes: disabled persons' despair, uncertainty, the feeling of lacking something, difficulties related to a job search and limited opportunities to find a suitable job.

The disabled persons, having lost their job due to: health problems (My health wasn't good; I was exceeding the sick leave allowance limit and they couldn't extend it anymore), unstable financial situation of a company (There was a redundancy situation at work), on the company's initiative (It was becoming more difficult to work and the company fired me; I left against my own will; It was getting harder and I was fired), the workplace did not satisfy their needs (I couldn't do any hard work; I couldn't walk and didn't return to work; I used to work 12 hours a day), got hit by the "emotional crisis", which causes their despair (I was looking for some activity but none has offered me anything), 
uncertainty (I was lacking something), fear (I acquired more fears), sadness (I became very sad, I shut myself down). Furthermore, the disabled persons face difficulties while looking for a job (didn't find a job), however, their constant search (I approached the labour exchange by chance; I was looking for some activity) makes them approach social care/welfare institutions, where they expect help. The persons with disabilities have limited opportunities to find a suitable job due to the lack of their qualification and psychosocial skills.

The context is being formed by the following categories: submitting the information, maintaining the relationship, mediation functions while looking for a job, and financial support.

Disabled persons' attitude towards the services provided by social care/welfare institutions partially depends on their needs and the support they get during the first meeting. In such a way the feeling of security is being developed. The disabled persons become more active having been given the necessary information, (I had a chance to talk to a school representative and everything became very clear to me then; I participated in a meeting; I asked immediately what I could do; The specialist told me that could send me for a training), when the relationship with them is being maintained (I was received in a very nice way, consulted and shown everything; The process was easy, everyone accepted everything and gave referrals), get support while looking for a job (They helped me to look for a job; Social worker helped me to prepare for a job search; I was advised to go for an accountancy training), and the financial support is provided (I was given some money, got a bursary). The services, provided by the labour exchange, are acceptable for disabled persons and they develop the feeling of security. Labour exchange keeps in touch with vocational training centres; different meetings are arranged as well as vocational rehabilitation is being promoted. The disabled persons are advised to undergo vocational consultation and orientation.

The difficulties, experienced by disabled persons and their current situation predetermine their choice and prompt their visit to the labour exchange, where they are provided the required services. Consequently, the disabled person is being advised to undergo vocational training or rehabilitation or a change of vocational qualification. During such a process the disabled person's "intervening conditions" can be met, i.e. the lack of knowledge and practical skills (First of all I wanted to acquire knowledge; I didn't have the senior secondary education and did not know what I could finish), health as an obstacle for vocational adaptation (My disease is not so simple; Nobody wants to employ a sick person; Would employers offer me a job at once, just like that), financial difficulties (I needed a job, did not have any money to study, yet what they were offering was acceptable for me). The disabled persons are offered vocational training, which is aimed at their abilities and skills after the vocational 
consultation stage. After wards, they are suggested to undergo vocational rehabilitation, during which not only vocational training but also rehabilitation improvement of their physical health - is offered. Other services, such as consultations with a psychologist and social worker, are provided too. The disabled persons also receive a bursary.

The action and interaction strategy is partially related to the context and intervening conditions. The action and interaction strategy itself can predetermine the disabled persons' positive attitude towards social care/welfare institutions, serving as a "bridge" towards the successful integration of the disabled persons into the labour market. Having approached the labour exchange, the disabled persons are advised to undergo vocational consultation and orientation (I was offered by the labour exchange; I was received in a very nice way, consulted and shown everything; I was advised to undergo an accountancy training). The next stage is vocational training and rehabilitation (The acquired qualification will be sufficient for me; Due to health problems I have been referred for massages, which I attended; My instructor helped me to buy everything I needed), which meets the disabled person's needs and abilities and the benefit of provided services (They provided information, showed interest and care; They helped me to look for a job; I acquired both knowledge and practical skills). Yet, one important aspect must be constantly observed: to ensure the high quality of provided services, to offer a wide spectrum of specialities and approachable conditions.

The consequences are interrelated with emotional satisfaction due to the ongoing changes (I learnt many new things, became younger; My free time and work are interrelated; I am planning to continue doing the same; I am feeling better, everything has changed and I feel the benefit of it), given attention and support by the specialists (They were very understanding as they understood that they were dealing with sick people; They provided information, showed interest and care; Professional and supportive pedagogues), created new opportunities (They helped me to become self-employed), adjustment of the working place in accordance with the disabled person's needs and opportunities (employment) (The internship place has become a workplace; the labour exchange has created a workplace specially for me).

Towards the quality of life: "I want the quality of my life to improve" this is the second phenomenon, having occurred during the job search. This phenomenon highlights that the successful integration of disabled persons into the labour market depends solely on themselves.

Phenomenon - towards the quality of life.

The causes, influencing the needs of disabled persons to improve the quality of their life while looking for a job, are the following: Lack of higher education (I wanted to acquire a qualification; I wanted to renew my knowledge); the need 
to socialize (I wanted to meet new people, new environment; There is no need to shut down oneself and sit at home; I was looking for some activity; There was very little socialization); emotional motivation (I wanted to be busier and not have time to think about my disease), personal determination (When I came to know about such a school, I decided that it is not worth hesitating).

Context. When seeking to improve the quality of life one's educational needs (I would like to gain more knowledge as everything is changing and improving; Improve my knowledge; I don't want to stagnate), being personally active (I wanted to acquire a qualification; I was looking for a job myself); a wish to be independent (I enquired and I am needed, yet I would like to be selfemployed; This is more convenient and I would like to be independent) are of crucial importance.

Intervening conditions. A disabled person's aspiration to seek for a better quality of life can be influenced by his/her family's support and motivation (My family supported me a lot that is why I am here; My family pushes, supports me; If their attitude was negative, I wouldn't have come here), by health being an obstacle for vocational adaptation (I had to adjust my working pattern to my health; I didn't think that my health would worsen so much and I would not be able to work), by financial difficulties (I do not have any financial opportunities; I got the bursary for 6 months, yet the training took one year).

Action and interaction strategy. The disabled persons find the activities, which they take an active part in during their vocational rehabilitation process, of vital importance. They state such activities help them to create a better future and seek for a better quality of life, despite the occasionally arising difficulties. The below activities prevail: improvement of social competences (I would like to have the courage to apply for a job; I need to see people, observe what is happening in the world), improvement of life skills (I liked our meetings, when we did various personality tests, created our CVs, it was really helpful; I would like to have more of such workshops, studies independently (You need to improve these skills; I am studying independently, watch YouTube videos, read independently), interest in employment opportunities (First of all I was looking for a job, yet when couldn't find, went for vocational rehabilitation; I was looking for a job, yet there were no free vacancies; The opportunities aren't so good, yet these are advertised everywhere; I knew that I could either work in a salon or at home according to a suitable schedule).

Consequences. The disabled persons' active participation while seeking for a better quality of life: taking part in potential activities and assessing their opportunities in an adequate way results in the following consequences: being socially active (I would like to establish an association or another group with people having similar diseases; I found new friends), the expectations having come true (My expectations have come true; I am encouraging others to go for 
vocation training; Others are afraid to leave home, others take care of children; Yet it is possible to find time, I did), better quality of life (I feel that something has changed for the better; I feel good already now), employment (I am selfemployed; I have chosen the best option for myself).

\section{Results of the Study}

During the process of selective coding the central phenomenon is identified, whereas other phenomena are being "broken" and further and more detailed data analysis is done. While analysing the given data, the following core phenomenon has been identified - optimization of the employment process. The below in vivo „I was really eager and got huge support: not only from the centre but also the community ", revealing the phenomenon in the best way, has been adjusted to it (Figure 1).

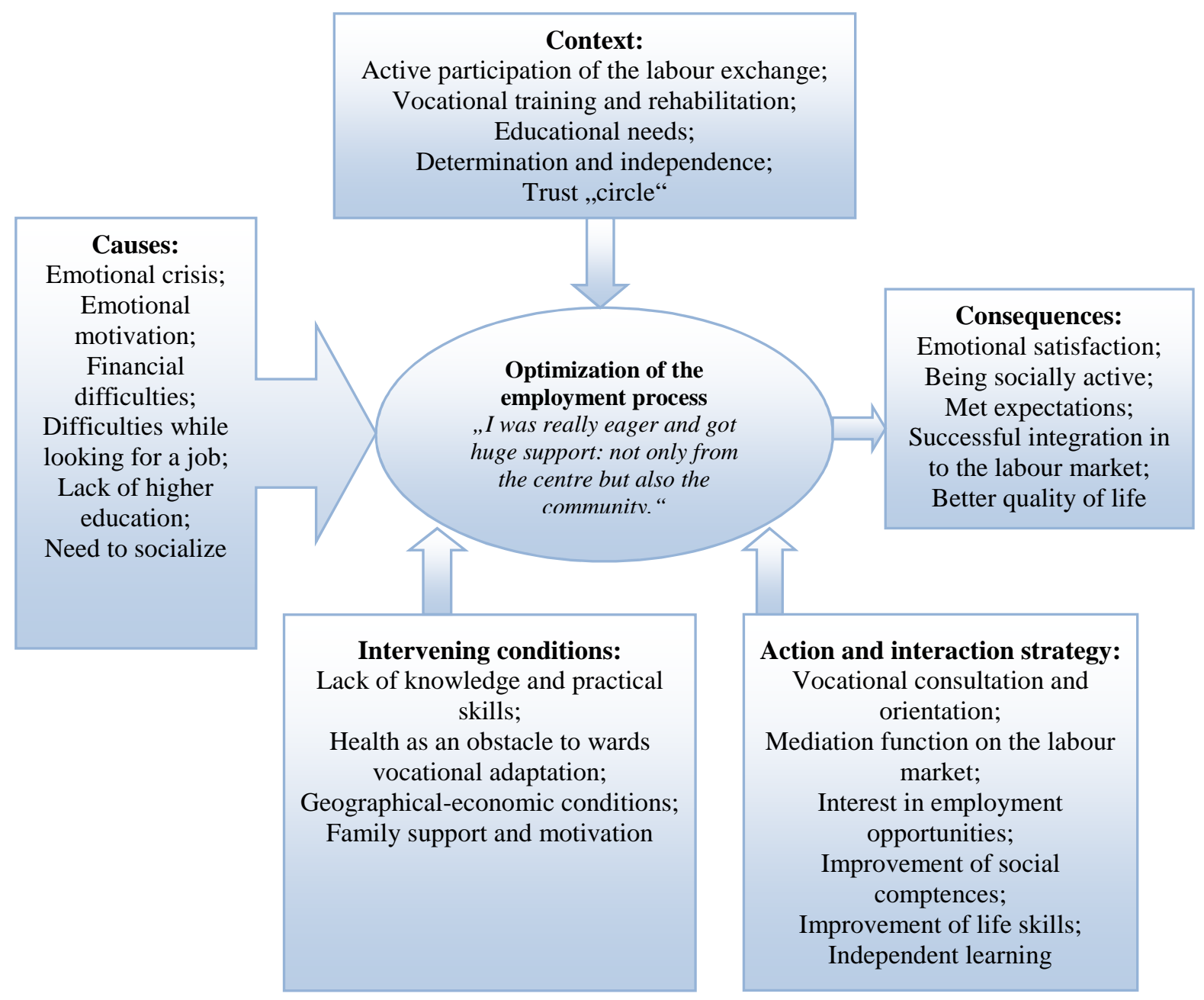

Figure 1 Central phenomenon - Optimization of the employment process 
The causes of this phenomenon are predetermined by the physical health, psychosocial health and financial difficulties, experienced by disabled persons, i.e. their current or past life situation. The disabled persons, having lost their job due to worsened health, are hit by the emotional crisis, face financial difficulties and difficulties related to a job search. However, simultaneously, other causes such as emotional motivation, lack of higher education and the need to socialize, occur. Due to the arisen difficulties the disabled persons start an active job search and get interested in what and how they could do, i.e. ,,search for a new way“.

Context. Optimization of the employment process of disabled persons is predetermined by the close institutional (active participation of the labour exchange) cooperation (vocational training and rehabilitation) as well as active participation of the disabled person in the employment process. Personal features (determination, independence) of the disabled person, educational needs (I would like to gain more knowledge as everything is changing and improving; Improve my knowledge; I don't want to stagnate), are also equally important.

Such intervening conditions as the lack of knowledge and skills, health as an obstacle towards vocational adaptation as well as geographical-economic conditions highlight the need for vocational rehabilitation to be organised in such a way so that it is easily accessible by all disabled persons. Thus, social care/welfare institutions play an important role in providing the required information for the disabled persons, increasing their performance and extending the job search for disabled persons. Likewise, the disabled persons also need to get their family's support and motivation as this constitutes an important condition for the formation of the disabled person's inner motivation.

Action and interaction strategy. These strategies comprise both active institutional participation as well as an individual's active independent participation. Vocational consultation and orientation, provided by an institution, helps the disabled person to choose the profession, improves his/her social competences and life skills in order to increase and enable his/her social participation. Mediation provided by the labour exchange is of great importance as it helps to maintain the contact and relationship between a disabled person and an employer not only during the job search itself but also during the process of employment and adaptation at the workplace. However, this becomes complicated in case a disabled person turns being indifferent and does not take any interest in employment opportunities. Personal inner motivation and adequate assessment of one's own situation encourages independent learning: deepening the gained knowledge and improving skills.

Consequences. of the employment process - when not only the disabled person is being enabled but also the institutions actively participate by mediating, cooperating and carrying out transparent work of the labour exchange Active participation of all participants in the process results in such consequences: 
emotional satisfaction (I learnt many new things, became younger; My free time and work are interrelated; I am planning to continue doing the same); being socially active (I would like to establish an association or another group with people having similar diseases; I found new friends), the expectations having come true (I am encouraging others to go for vocation training; Others are afraid to leave home, others take care of children; Yet it is possible to find time, I did), successful integration into the labour market (I am self-employed; I have chosen the best option for myself; the labour exchange has created a workplace specially for me), better quality of life (I feel that something has changed for the better; I feel good already now).

\section{Conclusion}

1. In accordance with the strategy of the grounded theory a model for the successful integration of disabled persons into the labour market has been created.

2. The model can be further used in order to improve the vocational rehabilitation process and, consequently, increase the number of employed disabled persons and ensure the benefit and importance of their provided services. Such integration does not only improve the employment indicators of disabled persons but also contributes to their socialization and wellbeing.

\section{References}

Baranauskienė, I., \& Juodraitis, A. (2008). Neįgaliųų profesinė reabilitacija: sėkmės prielaidos. Šiauliai: VŠI Šiauliu universiteto leidykla.

Bond, G. R., Resnick, S. G., Drake, R. E., Xie, H., McHugo, G. J., \& Bebout, R. R. (2001).

Does competitive employment improve non vocational outcomes for people with severe mental illness? Journal of consulting and clinical psychology, 69 (3), 489. http://dx.doi.org/10.1037/0022-006X.69.3.489

Corbin, J., \& Strauss, A. (2008). Basics of Qualitative Research. Techniques and Procedures for Developing Grounded Theory. California.

Drebing, C. E., Bell, M., Campinell, E. A., Fraser, R., Malec, J., Penk, W., \& Pruitt-Stephens, L. (2012). Vocational services research: recommendations for next stage of work. Journal of rehabilitation research and development, 49 (1), 101-120. http://www.rehab.research.va.gov/jour/2012/491/drebing491.html

Lithuanian Labour Exchange, Results (2015). https://www.ldb.lt/Informacija/Paslaugos Asmenims/Puslapiai/prof_reab_rezultatai.aspx

Mueser, K. T., Becker, D. R., Torrey, W. C., Xie, H., Bond, G. R., Drake, R. E., \& Dain, B. J. (1997). Work and non vocational domains of functioning in persons with severe mental illness: A longitudinal analysis. The Journal of nervous and mental disease, 185 (7), 419426.

Pranskūnienès, R. (2013). Nardinantis interaktyvumas muziejinejje edukacijoje: grindžiamoji teorija. Doctoral dissertation.Social Sciences, Educology. Klaipèda. 
Petruškevičiūtè, A. (2015). Galiu perskirstymas edukacinèje sqveikoje produktyviojo mokymosi salygomis: grindžiamoji teorija. Doctoral dissertation. Social Sciences, Educology. Vilnius.

Roessler, W. (2006). Psychiatric rehabilitation today: an overview. World Psychiatry, 5 (3), 1517. http://www.psikiyatri.org.tr/uploadFiles/publicationsFile/file/WP_October_06. pdf\#page $=25$

Siu, P. S., Tsang, H. W., \& Bond, G. R. (2010). Non vocational outcomes for clients with severe mental illness. Journal of Vocational Rehabilitation, 32 (1), 15-24.DOI: 10.3233/JVR2010-0491

Strauss, A., \& Corbin, J. (1990).Basics of Qualitative Research. Grounded Theory Procedures and Techniques. California.

The Order of the Minister of the Social Security and Labour and the Minister of Health of the Republic of Lithuania on the Description of the Criteria for the Assessment of the Level of Working Capacity and Approval of the Description of the Procedure for the Assessment of the Level of Working Capacity, dated 21 March, 2005 No. A1-78/V-179 Vilnius. 